\title{
Credit Markets and the Control of Capital
}

\author{
JOSEPH E. STIGLITZ
}

Traditional discussions of the role of capital markets have identified a number of distinct functions which they perform: they allocate scarce capital among competing users and uses, ${ }^{1}$ and they provide signals to guide managers in making their investment decisions. ${ }^{2}$ In this lecture, 1 wish to focus on a rather different function of the capital market: what I shall refer to as the control of capital. ${ }^{3}$

Conventional theory treats the typical firm in an anthropomorphic manner: it acts as a single, rational, individual doing what it is supposed to be doing, maximizing stock market value. That may have been well and good in those nostalgic bygone days of small firms, each run tightly by their owners who were single-mindedly pursuing their lust for wealth. But today a majority of production occurs in large corporations, in which no shareholder owns more than a small fraction of the shares, in which the separation of ownership and control that Frank Knight was so concerned with in his writings some sixty-five years ago has become a reality. Those

Financial support from the National Science Foundation is gratefully acknowledged. This paper was written while the author was a visiting scholar at the Hoover Institution, Stanford University. He is indebted to Franklin Allen, Bruce Greenwald, Sandy Grossman, Oliver Hart, R. Gilbert, M. Spiegel, and A. Weiss for extensive discussions on the subject of this lecture.

'This is the role which I have, for instance, discussed extensively in Stiglitz (1982b). See also Stiglitz (1981).

${ }^{2}$ Tobin's q theory emphasizes this role of the stock market.

${ }^{3}$ This is not meant to be an exhaustive list of the functions performed by credit markets. Elsewhere, for instance, Grossman and I have emphasized the role of prices in conveying information from the uninformed to the informed and in aggregating information (see Grossman and Stiglitz 1976, 1980b).

JOSEPH E. STIGLITZ is professor of economics, Princeton University. The Money, Credit, and Banking Lecture was delivered on June 26, 1984, at the meetings of the Western Economic Association in Las Vegas.

Journal of Money, Credit, and Banking, Vol. 17, No. 2 (May 1985)

Copyright (C) 1985 by the Ohio State University Press 
who manage these corporations control enormous amounts of capital. If they perform their functions well, the economy, and the shareholders of the firms, will prosper. If they do not perform their functions well, or if they divert the resources of the firm to their own personal use, both the economy and the shareholders will suffer. The question which I wish to address today is, what are the mechanisms in our society by which we ensure that those entrusted with the management of these resources do their job well? What are the institutions by which "control" is exerted over those who control capital? Are they effective? Could they be made more effective?

At the onset, it may be useful for me to present an overview of the argument which I shall present. In the first section, I shall review the traditional theory of the firm - the owner-managed firm. In this view, when the owner himself does not manage the firm, managers manage in the shareholders' interest; banks are like suppliers of pencils or toilet paper; each supplies a necessary ingredient in the production process of the firm, and there is no more reason to ascribe control to banks than to suppliers of these other inputs. There was a Populist view, common in the late nineteenth century, that banks were running the country; and there has been a continuing tradition in economics (particularly among institutional economists) that, even if banks do not run firms, managers do, in their own interests, and not necessarily in the interests of the shareholder. Modern theorists have, for the most part, dismissed this view: they have argued that there are mechanisms which ensure that managers who do not act in the interests of their shareholders get replaced. I would like to think of this as a triumph of theory over facts, which would bode well for theorists like myself; in fact, it appears to be more a triumph of ideology over theory and fact. The fact of the matter is that economic theory, taking into account costs of information, risk aversion, and the "public good" nature of management, is more consistent with what I shall loosely refer to as the Populist view than with what I shall call the nineteenth-century model of the firm. ${ }^{4,5}$ Shareholders do not control the firm, and managers do not necessarily act in their interests.

Although I do not prove any theorems in this paper, I draw upon recent developments in the economics of information, particularly those developments which have focused on the problems of control (what have come to be called "principal-agent" problems), in which one individual attempts, through indirect control devices, to induce another to act in his own interests. ${ }^{6}$ We argue that the problem at hand may most appropriately be viewed as a multiple-principal-agent

\footnotetext{
${ }^{4}$ These attempts to encapsulate broad theories in single sentences will, no doubt, offend partisans of all these theories; any linking of these theories with particular periods will no doubt offend historians of economic thought. My only apology is that space limitations make some caricature of these opposing views necessary, and that in any case, the caricature serves the useful function of bringing out more clearly the particular views that I wish to stress.

SThus, no particular novelty is claimed for the conclusions we reach; rather, the objective of this paper is to put what appears to be a currently unfashionable theory on firmer footing.

There has been a recent resurgence of interests in the problems discussed here, marked most notably by a recent conference at the Hoover Institution on Corporations and Private Property (the papers of which were published in the Journal of Law and Economics). The views of many of those papers are at variance with those presented here.

${ }^{6}$ For references and a fuller description of these theories, see below, section 2 .
} 
problem, for which it is known that the Nash equilibrium is constrained Pareto inefficient. ${ }^{7}$ Thus, the model of the firm that we present in section 2 represents an interpretation of this general multiple-principal-agent problem; in section 3 we examine the particular biases in resource allocations which it induces. In the fourth section, we suggest some reforms in our institutions which might alleviate some of the problems we have identified.

\section{THE TRADITIONAL VIEW}

In the model of primitive capitalism, with each firm controlled by a single owner, it is commonly argued that the issues with which we are concerned do not arise: because the owner-manager gets to keep the fruits of his labors and must bear the costs of any mistakes that he makes, he will have every incentive to exert the correct level of effort and to make the correct decisions. This view, however, is correct only if the probability of default of the firm is zero, an assumption which is as unrealistic for nineteenth-century firms as it is today. When a firm defaults, part of the costs of the mistakes of the firm that lead up to the default are borne not by the individual making the decision, but by his creditors. The recognition of this served as a serious impediment to the development of the limited liability firm. ${ }^{8}$ The fact that the owner does not bear the full consequences of his actions has two important implications: the owner-manager has an incentive to undertake riskier actions than he otherwise would $;{ }^{9}$ and the lender has an incentive to attempt to control, through one means or another, the actions of the borrower. We shall return later to the mechanisms by which lenders can exercise their control.

As we have suggested, the nineteenth-century model of owner-managed firms is highly inappropriate for modern capitalist economies. Some managers are endowed with a sense of corporate responsibility: they maximize the stock market value of the firm because they believe that is what a good manager is supposed to do. They are

\footnotetext{
7The term "constrained Pareto optimal" is used to remind the reader that in evaluating the efficiency of the economy, we have explicitly taken into account the costs of information. The remarkable part of the Fundamental Theorem of Welfare Economics is that it identifies the particular set of assumptions under which the competitive economy is Pareto efficient; if there are incomplete markets (as there are) or if there is imperfect information (as there is), then the economy is not, in general, constrained Pareto efficient (see Greenwald and Stiglitz 1984). Though Greenwald and Stiglitz establish that there exists, in principle, interventions in the market (e.g., taxes and subsidies) that can make everyone better off, a legitimate question to ask is whether the interventions that would occur through the political process would indeed be Pareto improving. We take no position on this issue. In the last section, we do, however, suggest some reforms which might improve matters; but we do not necessarily argue that they should be implemented by legislation, though to the extent that legislation impedes their introduction, it may be desirable to alter it.

It is worth noting that the information problems with which we are concerned here also affect the structure of competition in other ways; for instance, they naturally lead to the use of long-term relationships (see Stiglitz and Weiss 1983).

${ }^{8}$ For a discussion of this, see Allen (1980).

${ }^{9}$ If the owner-manager were risk neutral, then his payoff function (under limited liability) is $\max [R-(1+r) B, 0]$, where $R$ is the return to the project, $(1+r) B$ is the amount that the firm owes its lenders. ( $B$ is the debt; $1+r$ is what is owed on the debt.) This is a convex function, and hence the owner-manager acts in a risk-loving manner. Even if the owner-manager is risk averse, he will act in a less risk averse manner (in the sense of Diamond and Stiglitz 1974) than he would have in the absence of limited liability (see Stiglitz and Weiss 1981).
} 
individuals who are programmed to act in that manner; and the selection process of managers entails, in part, a search for individuals who are so programmed. ${ }^{10}$ But an important part of standard economic doctrine is that individuals do what is in their own self-interest. Why is it in the self-interest of nonowner-managers to maximize, say, the stock market value of the firm?

Three arguments have been put forward - stockholder meetings, takeovers, and "voting with dollars." I shall now show why none of these is very effective as a control mechanism.

\section{The Failure of Stockholder Meetings}

The stockholder meeting is the forum by which, in a strictly formal legal sense, stockholders control the management; they can — and in principle should - replace any manager who fails to take those actions which maximize the stock market value of the firm. In practice, there is considerable evidence that such meetings are usually controlled by the management, and theoretical considerations suggest that this should be the case. Any shareholder views himself as having a negligible effect on the outcome. Since there is always some cost associated both with obtaining information to determine whether a manager is a good manager and with evaluating alternative management teams, in other words, to voting intelligently, and there is a negligible benefit, no rational shareholder should expend the resources required to vote intelligently. We have long recognized that the well functioning of the government is a public good, and that because it is a public good, there may be too little expenditure on resources to ensure that governments function well. But a publicly held corporation is like a (local) government. " Ensuring that it functions well is a public good for all those who own shares in the firm (or who are the firms' creditors)..$^{12}$

What is surprising then is not that shareholder meetings generally fail to exercise effective control over management, but that there are instances in which shareholder meetings have had an effect. ${ }^{13}$

\footnotetext{
${ }^{10}$ There is little doubt that much of human behavior is the result of some kind of conditioning and/or training. Most individuals when they vote do so because they believe it is their civic duty, not because they do a careful calculation of the expected costs and benefits of voting. Reward structures in most universities are such that they must rely almost completely on some vaguely defined sense of responsibility for individuals to carry out all the tasks that need to be performed in an efficient and effective manner. This is not to say that selfish (rational) considerations do not enter; only that one cannot explain behavior simply by relying on such considerations.

George Akerlof (1970) has provided an insightful "rational" explanation for such seemingly irrational behavior. Parents like their children to appear to be honest and to have other similar virtues, because these virtues are rewarded in our society. Ideally, they might prefer that their children appear to be honest but really be dishonest, for by doing so they would be able both to obtain positions in which they have control of resources and to divert these resources to their own uses. Unfortunately, or fortunately, it is difficult to train children to appear to be honest, while they are actually being dishonest. Given this, the "second best" policy is to train one's children to be honest.

${ }^{11}$ The analogy is discussed further in Stiglitz (1977).

${ }^{12}$ It has not yet become commonplace in our schools to indoctrinate children in the virtues of exercising their voting rights over shares in the way that it is conventional to instruct them on the virtues of voting in public elections.

${ }^{13}$ The fact that a risk-averse individual would be sufficiently widely diversified so that only a negligible fraction of his wealth would be tied up in any firm provides further justification for why a rational individual should not allocate resources to voting intelligently in shareholder meetings.
} 


\section{The Failure of Takeovers as a Control Device}

Takeovers provide a second mechanism by which capital markets are alleged to ensure that errant managers get replaced. Assume the managers were not maximizing the market value of the firm. Any individual could come along, purchase the firm, change the policy to the value-maximizing policy, and reap the resulting movement in value as the return to his good management. There are at least four reasons why takeovers have not (and are not likely to be) an effective control mechanism. $^{14}$

First, when it is observed that some firm is not performing well, it may be either because the management is not good, or because the assets of the firm are not what they appear to be. ${ }^{15}$ The insiders (the managers of the firm) are likely to be more informed in this regard than are the outsiders. Thus, when those who have a controlling interest in the firm are willing to sell their shares, ${ }^{16}$ it indicates that the individual or firm attempting the takeover has paid too much; if they refuse to sell, it indicates that the individual or firm attempting the takeover has paid too little: takeovers will only be successful when the firm taking over pays too much. ${ }^{17}$

While the presence of asymmetric information gives rise to problems, so too may the inability to keep information secret. It is costly to ascertain which of the many

Conversely, if individuals have a significant fraction of their wealth tied up in a firm, and if at the same time they own a significant fraction of the shares of the firm, so that they may be able to affect the outcome, then it is rational for them to allocate resources to ensuring that the firm is well managed. But such individuals are frequently those involved in management, and thus do not provide any check on management. For an explanation (arising out of imperfect information concerning the characteristics of different firms) of why the original owners of firms do not become fully diversified and retain a significant fraction of the shares of the firm they established, see Stiglitz (1982b).

Note that to the extent that such individuals do have an incentive to exercise control, they have an incentive to exercise it in a way that promotes their own interests. Their interests will not coincide with those of small shareholders. (This will be true even if they could not divert resources to their own use, at the expense of other shareholders, i.e., the only differences may be those due to differences in attitudes towards risk.) See Grossman and Stiglitz (1977, 1980a).

${ }_{14}^{14}$ Not all of these may be relevant in any particular situation.

${ }^{15}$ That is, given the past mistakes of the firm, the firm may now be doing as well with what it has as anyone else could do.

${ }^{16}$ This assumes that those who are in a position to determine (or significantly affect) the outcome of a takeover bid have the interests of shareholders as a whole at heart; often they do not, as we shall argue below.

${ }^{17}$ Takeovers are like buying "used firms" just as secondary labor markets are like hiring "used labor." Akerlof's (1970) original insight into the thinness of used car markets applies here, just as it does to the used car market (see Stiglitz 1975a; Greenwald 1984). The argument applies, however, with even greater force to this market than to the labor or used car markets. There, trade might occur because individuals have different abilities that are specific to different firms or have different tastes for quality of used cars. Here, it is only differences in ability to manage the firm's assets that are relevant. (With rational expectations, differences in beliefs alone cannot give rise to trade (see Stiglitz 1982b). For an application of this general result to takeovers, see Grossman and Hart (1981).) Without entering into the debate on the empirical literature assessing the effects of takeovers, let me simply assert that $I$ have not found much convincing evidence that takeovers result in significant increases in the productivity of the firm taken over. It appears common for the firm taking over to have its market price fall if it is successful. If this is true, it suggests that the market perceives the "success" of the takeover as evidence that too high a price has been paid, and it provides further evidence that firms (here the firm taking over) are not controlled by their shareholders.

Even when there are some firms who have a reasonable idea about the value of a firm, there will be relatively few such firms, and some firms may have a better idea than others. Thus, the appropriate model is not the standard, fully competitive model, but a bidding model with a limited number of bidders and possibly asymmetric information. 
firms in our economy are not very well managed and hence undervalued relative to their potential. Assume that some firm allocated resources to sift through a large set of firms to identify the most poorly managed one. It then made a takeover bid. This immediately provides a signal to other firms to evaluate whether the bid represents an underevaluation of the firm's true worth. If it does, they will then "bid" against the "discovery" firm; in equilibrium, the entry of these "secondary" bidders will drive their expected profits to zero; but this implies that the discovery firm, which has had to expand resources reviewing many firms that are not badly managed, has a negative expected profit. ${ }^{18}$

The third reason that takeover mechanisms are ineffective is related to the same "public good" argument that arose in our discussion of the inefficacy of stockholder meetings. If the takeover is successful, and if as a result the market value of a share is increased, those shareholders who have not sold out get a free ride; since each small shareholder believes that what he does will have no effect on the outcome (whether the takeover is or is not successful), it is in the interest of each to withhold his shares. ${ }^{19}$ Only if he believes that the takeover will be successful and will result in a decline in the value of his shares will he have an incentive to sell. ${ }^{20}$ Thus, whereas value-decreasing takeovers are easy (there is a rational expectations equilibrium in which all such takeovers are successful), value-enhancing takeovers are not. ${ }^{21}$

The fourth reason that takeover mechanisms are ineffective is that the current managers are often in a position to take strategic actions that deter takeovers. ${ }^{22}$ Though the most dramatic of these have only recently come to public attention golden parachutes, contingent sales of the firms assets, acquisitions that will result in antitrust violations if the takeover is successful - other actions, such as long-

${ }^{18}$ See Stiglitz (1975a). Firms will, in general, employ mixed strategies in making their takeover bids or in deciding whether they should evaluate a takeover bid to decide whether to compete.

"If there are well-developed option markets, presumably the individual could participate in any gain and at the same time sell his shares; these option markets have resulted in the creation of a class of securities that is formally equivalent to nonvoting shares.

${ }^{20}$ Note that this problem does not arise when there is a single shareholder. Then (ignoring the problem of asymmetric information discussed in the previous paragraph), one can think of the firm as continuously being on auction. It will be sold to the bidder who believes he or she can earn the highest return from the assets (and the rent will equal the difference between the value of those assets to him or her, and to the next highest bidder; with a large number of bidders and no significant differences in comparative advantages in management, this will be essentially zero. Although this argument explains why assets might be efficiently utilized in a "primitive capitalist economy," it does not work well for modern capitalism: no entrepreneur has sufficient capital to acquire all of the shares in any one of the major industrial firms; if he did succeed, he would probably not be able to be sufficiently widely diversified to act in a risk-neutral manner; and if he succeeded, he would have had to rely on considerable borrowings from financial institutions, which will impose important constraints on his behavior - a central theme of this lecture.

Grossman and Hart (1980) have emphasized this explanation of the inefficacy of the takeover mechanism. They argue that, as a result, the only way that those taking over a firm can get compensated is through diverting the firm's resources to their own use. But if those who increase the efficiency of the firm can do so, so can those who fail to increase the efficiency of the firm: it is difficult for an outsider to assess whether the firm is or is not being managed efficiently.

${ }^{21}$ This analysis clearly depends on the rules confronting the firm attempting the takeover. Takeovers can be made easy if the firm taking over can offer to buy only 51 percent of the shares and can then take actions that dilute the interests of the minority shareholders. But as we note below, rules that make value-enhancing takeovers easier may also make value-decreasing takeovers easier, and may indeed result in the nonexistence of equilibrium. See Stiglitz (1972).

${ }^{22}$ For a discussion of some of these devices, see Cary (1969-70). 
term contracts with large penalties for breach of contract, restrict the scope of action of any firm attempting to take over another firm and thus make the takeover less attractive. ${ }^{23}$

\section{Voting with Dollars}

There is a third control mechanism that is often postulated: in analogy to the Tiebout (1956) model, in the theory of local public goods, where individuals vote with their feet, here individuals vote with their dollars. Firms that do not use resources efficiently will not be able to raise additional capital. There are, however, important limitations to this mechanism (as with the previous two): it is only effective to the extent that capital must be raised from the market; the managers of firms have considerable discretion over their cash flow. For some firms, with good investment opportunities (exceeding their cash flows), the "bribe" of future capital induces desirable behavior today. (And even then, what being "good" means need not correspond to "efficient utilization of resources.") But for other firms, with poor investment opportunities, the threat of the denial of access to future capital is not an effective control mechanism.

Note, moreover, that when firms do return to the market for additional capital, they almost invariably turn to banks. There are two reasons for this. The first (which is discussed in Greenwald, Stiglitz, and Weiss (1984)) is that resorting to the issue of equities often provides a signal concerning the "quality of the firm" and depresses the price of the shares. The second, which is the subject of this paper, is that raising capital through banks results in more effective control over capital than raising it through equity markets. ${ }^{24}$

\section{Consequences of the Failure of Control Mechanisms}

I have argued here that the standard "control mechanisms" - whether they were or were not effective in the days of primitive capitalism - are at best of only limited

\footnotetext{
${ }^{23}$ These are not the only problems with takeovers. If the takeover entails less than 100 percent of the shares, then the firm taking over may be able essentially to divert all of the resources of the firm to its own use. Thus, the firm that is willing to bid the most in a takeover model is not necessarily the one that will use the resources most effectively, but the one that is most effective in diverting the resources to its own use. Fraud laws do not stop this diversion, and indeed may put some firms (downstream or upstream suppliers or purchasers) at an advantage relative to other firms.

But what is at issue is more than just fraud or the diversion of the resources of the firm to the personal use of managers. Assume that there are three or more groups of individuals in the population with honest differences in opinion about how the resources may be best used. Then, type $A$ individuals can buy out a majority of the shares from type B and change the production plan of the firm. Those who sell out - those among current owners who are most pessimistic concerning the firm's prospects - may be slightly better off; those who do not sell are worse off. This is true whether current market price goes up or down; type B individuals believed that, under the original production plan, their expected return was greater than from other assets (but there were sufficiently few of them that the marginal purchaser of shares was an individual of another type, say C). At the same time, once A controls the shares of the firm, type B individuals could buy out a majority of type A individuals. There is no equilibrium. Implicit in this analysis is an assumption of imperfect competition: individuals enjoy some "surplus" out of the ownership of the stock of a particular firm; the demand curve for the shares of the firm are downward sloping. There is considerable evidence in support of this "monopolistic competition" view of the stock market (see Stiglitz 1972a, 1974, 1975b).

${ }^{24}$ These are not the only alleged control mechanisms in a capitalist economy. For instance, there are evolutionary arguments which suggest that firms who manage their resources efficiently will survive, while those that do not will not. For some criticisms of this argument, see, for instance, Stiglitz (1974, 1982a).
} 
effectiveness in modern capitalist economies. Empirical evidence in support of my position is hard to come by: an essential part of the argument is the difficulty outsiders face in determining whether a firm is or is not efficiently managed. Still, there is both direct and indirect evidence in my support. First, the one aspect of technology that is "public" concerns taxes and tax-avoidance behavior. There is a considerable body of evidence supporting the view that a significant fraction of firms do not act in such a way as to minimize tax burdens (including both direct, i.e., corporate, taxation, and indirect taxation, the taxes shareholders and suppliers of credit must pay). (For a review of these tax "paradoxes," see Stiglitz (1982a).) ${ }^{25}$ Second, the persistence, over an extended period of time, of closed-end mutual funds selling at a discount (implying that the managers had, at each moment, a strategy that would lead to an increase in market value), and the difficulties that the few takeovers which were attempted encountered, provides corroborating evidence. (This is similar to the resistance of many managers to "asset stripping takeovers," even when the value of the stripped assets is considerably more than the current value of the firm.) Third, the behavior of managers in many of the recent takeover wars seems more consistent with the view put forward here than with the standard view. ${ }^{26}$

\section{BANKS AND THE CONTROL OF CAPITAL}

Our problem can now be simply put: how do we ensure that, in a capitalist economy, those entrusted with the management of its resources, the managers of our largest corporations, manage those resources efficiently. ${ }^{27}$ I have argued that the traditional control mechanisms are not effective. The central thesis of this paper is that, to the extent that control is exercised, it is by banks, by lenders, and not by the owners of equity, in spite of the legal form that invests responsibility for control in the hands of the owners of equity. But before arguing this, and exploring its consequences, 1 need to explain at greater length what I mean by control.

Both the concept of control and its ambiguity are familiar to most of us from ordinary usage: we talk about losing control of our children, but then admit we

\footnotetext{
${ }^{25}$ It would be worth knowing whether the incidence of such seemingly anomalous behavior is greater among managerially controlled firms than among owner-managed firms.

${ }^{26}$ I realize, of course, that, to true believers in the religion of efficient markets and efficient firms, these arguments will not be completely persuasive. There may be Ptolemaic arguments by which each piece of evidence might be reconciled with what I have loosely termed "traditional" theory. My objective here is to present a simple, alternative theory that is consistent with the evidence and in which things are what they seem to be: behavior that appears to be inconsistent with value maximization is in fact inconsistent with it.

Note, however, that the argument that value-decreasing takeovers may be successful may provide a rationale for managerial resistance to takeovers, which is consistent with shareholder interests.

${ }^{27}$ As I have mentioned earlier, what is at stake is more than simple fraud; that, presumably, might be taken care of by direct legal remedies.

There is a view that managers make little differences to the performance of firms. The evidence usually cited is that changes in management do not have a significant effect on firm performance. This could be either because the selection process is sufficiently effective that good managers are replaced by good managers or because managers make no difference. (Alternatively, and probably more reasonably, though incompetent managers clearly can destroy a firm, within the range of those who appear to be good, the effect may be relatively small.)
} 
never had it; we ask who runs (or controls) the university, but a single source of power appears to be elusive. In the present context, managers of the firm have "responsibility" for the management of certain assets; they can assign them to one use or to another. We say they control the disposition of those assets. But their control is not unfettered. They (the corporation which they manage) have received its resources (capital) from banks and from suppliers of equity. Each, in supplying capital, has imposed conditions on the manager, which circumscribe his actions, which limit his freedom. ${ }^{28}$ The constraints which each can impose are markedly different. The equity owner cannot demand the return of his funds (he can try to persuade another individual to purchase his shares, but once he has turned over the capital to the manager, he cannot force the manager to give him back his money.) He can exercise his vote in a shareholders meeting. The lender sets a term to the loan; at the end of the term, he can insist on his money back. If the manager fails to comply with his request, the lender has certain rights of intervention, defined both by the loan contract and by statutes. The lender has the right to intervene in other well-defined circumstances. The loan contract may, for instance, impose restrictions on additional loans, on what projects the firm may undertake, etc. ${ }^{29}$ Note that the rights of the lender to get his money back are circumscribed. But they are undoubtedly less circumscribed than the rights of the equity owners to get their money back.

The terms of the contract are both explicit and implicit. Implicit contracts are enforced not through law but by other means: a borrower who fails to comply with the terms of the implicit contract may fail to have his loan renewed (and a lender who fails to renew a loan, all of the implicit terms of which have been complied with, may find it difficult to find willing borrowers) ${ }^{30}$ Controllers control controlees not only directly, by imposing constraints on the set of actions which the controlled can undertake, but also indirectly, by designing reward structures which induce the controlled to take actions that are (more) in accord with those attempting to exercise control.

Thus, managers are partially controlled, directly and indirectly, through both explicit and implicit contracts and by both lenders and shareholders. The lenders exert control through both the formal terms of their contract and their refusal to renew a loan; shareholders exert control through both the voting process and their refusal to provide additional capital. Managerial incentives are affected by both the explicit pay schedule - the rewards provided by other firms who might hire them away, provided their behavior is appropriate - and the implicit punishments provided by other firms in their treatment of those who are dismissed by their firms (or whose firms go bankrupt). Both the rewards and punishments and the constraints,

\footnotetext{
${ }^{28}$ These are not the only sources of constraints on his action. The legal system imposed other constraints; buyers and sellers with whom the firm has contracts impose still further constraints.

${ }^{29}$ In some cases, the law restricts the set of interventions that may be stipulated in a loan contract; if the lender takes too active a position in management, he may lose the advantages that the law assigns to creditors.

${ }^{30} \mathrm{As}$ in labor contracts, it is not the case that explicit contracts are necessarily better than implicit contracts. The enforcement of explicit contracts requires not only that violations be observable, but that they be verifiable by a third party, the court; this is not so for implicit contracts. On the other hand, while one-period explicit contracts are enforceable, for implicit contracts to be enforceable requires long-term relationships.
} 
which determine the action of managers, are set not by a single individual, and not even by the firm's shareholders and lenders, but by the market as a whole. ${ }^{31}$ No one controls the manager: a large number of individuals and institutions affect his behavior. While the earlier literature ${ }^{32}$ attempted to view the manager as the agent of the supplier of credit (the "principal"), with the supplier of credit designing an efficient incentive contract for the agent, ${ }^{33}$ a more appropriate model is a multipleprincipal-agent model, in which each principal is only allowed to set certain of the terms of the contract. These problems are, of course, ubiquitous in our economy, though they have received relatively little attention.

Let me give another example, where each of the principals has a natural set of controls. Consider a sharecropping economy, in which the tenant needs both capital and land to produce output. Assume that one individual owns the capital, the other land. Each writes a contract with the tenant specifying the compensation he is to receive for supplying his resource. The behavior of the individual is, of course, affected by the terms of both contracts. There is a kind of externality between the two contracts: an individual with a large outstanding loan may (in the presence of provisions for bonded labor) undertake less risk but supply more effort than he otherwise would have provided. ${ }^{34}$ There is, as a result, an incentive for the internalization of these externalities; for the landlord, for instance, simultaneously to provide credit, or at least to force his tenant to disclose what credit contracts he has. ${ }^{35}$ But for a variety of reasons, full internalization is frequently not possible. ${ }^{36}$ In those cases, there will not be a single principal controlling the agent. This is the situation, I contend, with large joint stock firms. There is no single principal controlling the manager.

When there are several individuals exerting control, we are wont to ask, who exerts effective control, or who is most important in exerting control? The question, I think, is a meaningful one, but is hard to translate into quantitative terms: clearly

\footnotetext{
${ }^{31}$ Thus, the threat of a lender to cut off credit would not have much force if the borrower could simply tum to other suppliers of credit. The threat of an employer to fire a worker would not have much force if the worker could simply tum to some other employer and obtain the same wage. Market equilibrium must be such that these threats are effective, that is, there is some cost to being fired or to having one's credit terminated by the bank that usually provides credit. For an analysis of equilibriums with this property, see Stiglitz and Weiss (1983) and Shapiro and Stiglitz (1984).

${ }^{32}$ This view was first put forward in Stiglitz (1974), where the analogy between the problem of the landlord, attempting to elicit effort from his workers, and the owner of capital, attempting to elicit effort from his manager, was drawn (see also Ross 1973). Since then, a huge literature on the principal-agent problem has developed, emphasizing not only the problem of eliciting the correct level of effort, but also the problem of ensuring that the manager undertakes the correct amount of risk.

${ }^{33}$ Although it should be emphasized that "efficient" in this sense is only a local concept, given the prices, etc. on the market, the principal cannot be made better off without making the agent worse off. The market equilibrium is not, however, in general Pareto efficient. See Amott and Stiglitz (1983a) and Greenwald and Stiglitz (1984).

${ }^{34}$ The externality is reciprocal: the terms of the tenancy contract affect the probability of default on the loan. For a more extensive discussion of these issues, see Braverman and Stiglitz (1982).

${ }^{35}$ For a more general discussion of these externalities in the context of principal-agent (moral hazard) problems, see Amott and Stiglitz (1983b). For an excellent discussion in terms of the multiple-principalagent problem, see Bernheim and Whinston (1984).

${ }^{36}$ Limitations on information may make it impossible to enforce "exclusive" contracts. Alternatively, a single principal may not have control of all the resources required by the agent. Thus, the landlord may not have sufficient capital or the required bullocks. Presumably, he could obtain these resources from the same supplier that the tenant does; but this would simply introduce a new principal-agent problem.

A further limitation may be imposed by the fact that if the principal supplies all the resources required by the agent, the principal becomes too dependent, for his welfare, on the behavior of the agent: there is insufficient risk diversification.
} 
agent $A$ exerts more effective control than agent $B$ if agent $A$ can impose all the same constraints and rewards that agent $B$ can, and then some. But usually, agent A can do some things that agent $B$ cannot, and conversely. Equity owners can do some things that lenders cannot (they can vote at shareholder meetings), and lenders can do some things that equity owners cannot. This is not the occasion to attempt a precise definition (and it is hardly necessary for my purpose). I hope that the intuitive notions that I will present here will suffice for the moment.

In determining who exercises effective control, what is relevant is not only the rights and means of intervention but also the incentives: intervention is only desirable if it effects an improvement in behavior on the part of the agent (from the point of view of the "intervenor"). To ascertain this, the intervenor has to be informed about both the current course of action of the manager and the alternatives. But information is costly.

Here we obtain the basic dilemma: if the manager were to receive all of his resources from a single supplier, then that supplier would have an incentive to gather information to ascertain that the manager acted in the interests of the supplier. But then the supplier would have to bear considerable risk; he might not be adequately diversified. On the other hand, it is not in the interests of any shareholder or small lender to devote much attention to the performance of a firm; for any gains that accrue to him as a result of his actions accrue to all similarly situated suppliers. There is the free-rider problem which we discussed earlier.

Thus, though both lenders and equity owners have certain rights to control managers, they do not individually have the incentives required to induce them to exercise those rights. The conclusion: managers are not effectively controlled.

If this were the end of the story, the prospects for large-scale capitalism would have indeed been dim. Given that managers could not be effectively controlled, no one would turn over to them the capital required for the development of modern industry. There are, however, three control mechanisms, which, though they work imperfectly, work sufficiently well that individuals are willing to turn over capital to others.

A. Banks. The most important of these, I suspect, are banks (both the lending banks and the investment banks, which assist in the raising of capital). Banks frequently take large positions in a firm; the nature of the loan contract enables them to do this without undertaking undue risk. At the same time, the nature of the contract enables them to focus their attention on information gathering to a particular set of issues: those associated with the probability of default and the net worth of the firm in those low-return states. They need not concern themselves with either how good the best prospects of the firm are or what the probability is that the firm will make off like a bandit.

Since they are concerned with low-probability events, and since the managerialincentives structure is such as to encourage managers to avoid those events, the payoff to banks exercising very effective control is limited. ${ }^{37}$ We shall return to this later.

\footnotetext{
${ }^{37}$ Collateral reduces the risk to the bank even further and, except for avoiding disastrous outcomes, also reduces the incentives for exercising close control.
} 
This argument says that the "public good of management" problem for lenders is resolved by having a single lender. This is not always the case: frequently there are syndicated loans, in which a single bank takes the "lead" position and undertakes responsibility for ensuring that the borrower is effectively controlled (from the perspective of the lender. $)^{38}$ Here, the problem of public management as a public good is resolved by means of reputation: it is in the interest of each bank to ensure that the loans on which it acts as the lead banker are good, lest other banks refuse to participate in the loans it attempts to syndicate. ${ }^{39}$

$B$. Concentrated equity ownership. In the case of debt, the problem was resolved by having a single supplier (or having the several suppliers act cooperatively). In the case of a large, widely held firm, the number of shareholders is sufficiently large and there is sufficient anonymity about who the shareholders are that the same mechanism will not work. But if there are a few shareholders, each of whom has enough stake in the firm that his private incentives for controlling the manager are sufficiently great, then there will be a sufficiently large expenditure on information acquisition by these individuals that effective control will be exerted. (The small shareholders will continue to "free ride" on the efforts of the larger shareholders; the standard arguments suggest that as a result there will be an insufficient expenditure on resources for controlling managers, at least from the point of view of the shareholders as a class.) This has a cost: the limited diversification which these individuals can achieve. Moreover, the interests of these shareholders may well not coincide with the interests of the small shareholders. ${ }^{40}$ Presumably, for individuals to be willing to undertake this limited risk diversification, they must be compensated, for example, by being allowed to divert some of the resources of the firm to their own use (such as high fees for being on the board of directors). ${ }^{41}$

\footnotetext{
${ }^{38}$ As usual, the problems of incentives and screening are hard to distinguish: the lead bank is also responsible for ascertaining the suitability of the borrower for the loan.

${ }^{39}$ The enforcement of cooperative equilibrium in multiperiod games has been the subject of extensive recent research. Though most of these studies have assumed no discounting, and therefore are of limited usefulness for our purposes, several recent studies have incorporated discounting. See, in particular, Abreu (1983).

As in the usual analysis, in a one-period model it would pay eacti bank to cheat: to syndicate a loan, but then to fail to expend the resources required to ensure that the lender used the funds properly. In a multiperiod context, this is not true. A bank that "lost its reputation" and could not syndicate its loans would have to bear greater risk. This "risk premium" can be viewed as the punishment for failing to exercise control. Note that the number of banks involved is sufficiently small so that each bank can assess the reputation of the other banks.

A similar reputation mechanism operates in the case of trvestment banks. attempting to raise capital by means of bonds. Then, the bank agrees to act as "trustee" for the bondholders, exerting certain control. The argument does not carry over, however, to investment banks attempting to raise equity capital. After the equity is raised, the bank usually plays no role in ensuring that the firm's managers do what they should. The responsibility of the investment bank is limited to that of screening. (This is not quite true for venture capital and private placements.)

${ }^{40}$ The fact that a wealthier individual owns more shares of a: firm does not necessarily imply that he has greater incentives for information acquisition and for exercising control: if the value of his time increases proportionately, then the cost of obtaining information rises with the return.

${ }^{41}$ If this were the only return extracted by such shareholders, it would be a small price to pay for the management of the public good. Unfortunately, apart from the other control mechanisms discussed here, there seems considerable discretion for the controlling shareholders and managers to cooperate in the diversion of resources from the common good of shareholders to their own benefit.

Note that there are other reasons for limited diversification: the original founder of a firm may wish to signal his confidence in the firm by retaining a considerable proportion of the shares (see Stiglitz
} 
C. Managerial reputations. The third control mechanism is the concern of the manager for his good reputation. Others, both in his firm and outside, are judging his behavior. If he behaves "well" then he is apt to be promoted or to be bid away by some other firm. If he behaves in a way that is perceived to be "bad," at the very least his outside opportunities will be reduced; at the worst the firm will go bankrupt, the creditors will intervene, and he will be out of a job. He always risks the possibility of an internal coup d'état: underlings or outsiders attempting to convince the board of directors that they could do a better job. ${ }^{42}$

Managers are affected, of course, not only by their reputations, but also by their compensation schedule. Some have suggested this as an explanation, for instance, for stock options. Interestingly enough, a recent study by Larson (1984) of stock option incentive plans instituted over an extended period of time showed that firms with these plans did no better (in terms of stock market value) than the market as a whole. There are few firms with managerial-incentive plans which are even roughly in accord with what economic theory would predict. ${ }^{43}$

\section{BIASES IN THE CONTROL MECHANISMS}

Shareholders do not control the firm. We have posited here a set of alternative control mechanisms. Managers do respond to these controls. I wish to argue that,

1982b). Firms that are controlled by the original founder represent a cross between the primitive capitalism discussed in section 1 and advanced capitalism under discussion here.

Just as the original founder of the firm may retain a significant fraction of shares in the firm to signal his confidence in the firm (and thus to increase the market value of the firm), so too has he an incentive to design the corporate charter in such a way as to provide "good incentives" to subsequent managers; presumably the market will reward him from doing so by increasing his current market value. Though there is obviously some truth in this argument, frequently when the corporate charter is drawn up, the founder has no intention of retiring; frequently, he has a contract with the firm which requires that he continue to provide certain services, for an extended period of time. Thus the present discounted value to designing contract terms that provide better incentives for some potential future manager, in ten, twenty, or thirty years time is likely to be small; the founder is best advised to direct his attention to other problems.

${ }^{42}$ The fact that the board of directors often includes many individuals from management should not obscure the fact that the different managers and different members of the board have different incentives: they need not act as a team. It is obviously risky for the president of a firm to attempt to overthrow the $\mathrm{CEO}$, but such palace revolutions are not that uncommon.

${ }^{43} \mathrm{~A}$ notable exception is the recently instituted executive compensation plan of TRW. Stock option plans reward the manager but not in terms of how his performance compares with others in comparable situations; such compensation depends on the performance of the stock market as a whole. Why should executives be forced to bear this risk? Doing so has one advantage in principle: managers should be more concerned with the correlation of the firm's return with the market. There is little evidence that this was an important consideration in the adoption of these plans or that it has been an important consequence of them. Indeed, if it were, contracts with managers should impose restrictions on their purchase of index options or other shares in the market. (Today, with futures markets, managers may be able to divest themselves of the market risk associated with being paid both options.)

The standard argument concerning the tax advantages are fallacious; indeed, quite the contrary, even if the pay were to be made dependent on the performance of the firm, it is advantageous to pay the bonus directly, rather than through stock options (see Stiglitz 1982a). (When 1 presented this argument recently to a conference in which a number of participants were responsible for designing the executive compensation programs for some large American firms, no countervailing argument was presented.)

It is interesting to note that when most stock option plans are instituted, the executive does not appear to bear more risk: they are introduced as supplements (allegedly at little cost to shareholders) to their salary structures. For a discussion of relative performance based incentive structures, see Nalebuff and Stiglitz (1983). 
as a result, firms do not maximize their stock market value; ${ }^{44}$ whether there are other institutional arrangements which would ensure that capital would be more effectively utilized is a question to which I shall turn in the next section.

There are systematic biases associated with each of the control mechanisms described in the preceding section. Lenders are only concerned with the bottom part of the tail of the distribution of returns. Thus, they may require that the firm undertake projects with relatively little (bottom-tail) risk, even though the expected return is much lower. (Or, they may induce the firm to do the same thing through their indirect control devices, the control of the terms of the loan contract, the conditions under which they renew credit, the collateral which they require, or the interest rate which they charge.) In reducing the probability of default, they ensure that the manager does not abscond with the firm's funds, and thus provide a public good for all investors. But in other respects, the interests of banks and equity owners are antithetical. The bank, because it can withdraw funds, is in a position to exercise control: managers respond to the demands of their bankers. ${ }^{45}$

Managers' concern for their reputation, and their knowledge that judgments will frequently be made (implicitly) based on their relative performance, means that they may "follow the pack." If convention has it that the firm should pay dividends, then the managers instruct the firm to pay dividends, whether or not it is in the best interests of shareholders. Any manager of a large, publicly held firm who attempted to explain the dividend paradox to his shareholders would be considered flaky, and his future prospects diminished. ${ }^{46}$ The firm's managers may ask the firm to pay them whatever convention dictates that managers of such firms get paid, regardless of the opportunity cost of the managers' time, and regardless of what it could obtain essentially similar managers for. Although the executives of the automobile industry were quick to claim their desserts for having brought the industry back to profitability (in spite of the significantly negative effects that these bonuses had on labor relations), they were not as quick to accept blame (and the commensurate pay reductions) when they led the industry to all-time losses. ${ }^{47}$ Managers are (at best) temporary trustees of the firm's assets, and their reward structures are for the most part directed at current returns: few firms compensate their managers on the basis of the firm's performance ten or twenty years hence. Few, if any, require that the individual retain shares in the firm long after they have completed their term as chief

\footnotetext{
${ }^{44}$ This in itself does not mean that the economy is not constrained Pareto efficient; resources are not being used as effectively as they would be if information were costless, but this is a relatively uninteresting statement. It is, however, well known by now that whenever there are principal-agent (incentive) problems, the economy is not even constrained Pareto inefficient (see Arnott and Stiglitz 1983b; Greenwald and Stiglitz 1984).

${ }^{45}$ The term of the loan poses an interesting problem to the lender. On the one hand, short-term loans give the lender a right to his money back (or to intervene) at any date; but lenders cannot continuously monitor, and in the intervening periods borrowers may take actions that make it impossible to repay. They thus force the hand of the lender: he either renews the contract or takes the risk of getting what he can out of bankruptcy. It may be more efficient for the lender to commit himself to supplying funds over a certain extended period, effectively giving up some of his rights to intervention (see Stiglitz and Weiss 1981).

${ }^{46}$ Presumably, by the time the individual has reached this rung of the corporate ladder, any such tendencies have been identified and the individual barred from further progression.

${ }^{47}$ So long as the firm is making record profits, the lenders have no interest in restricting these payments; equity owners do, but for the reasons we have given above, they have no effective control.
} 
executive. Yet the return on many long-term investments will not occur until some time in the future. Keynes, in the General Theory, expressed a concern that investors in the stock market were merely concerned with short-term gains, not the long-term returns. Today, increasingly, similar allegations are brought against the managers of many of America's largest enterprises: the heads of these enterprises are financial experts, not production experts. Their job is to allocate capital. And their perspective is not unlike that of the Keynesian investor: they wish to find underpriced assets, just before those assets are discovered by others, so that they can reap a short-term capital gain. Their behavior is not surprising: what incentive do they have to be concerned about the long-term prospects of the firm or the productivity of the economy? ${ }^{48}$

Small shareholders, since they cannot exercise control directly, must rely on the other control mechanisms. Large equity owners may have, as we have suggested, some incentives to exercise control, but their interests may well not coincide with those of the small shareholders. Similarly, though small shareholders may recognize that the interests of the lenders and those of small equity owners are not coincident, they know that the lenders' concern that the firm not abscond with the funds ensures some degree of safety for their investment; and that since managers in general have some stake in the outcome of the firm, their incentives will at least partially be coincident.

\section{INSTITUTIONAL REFORM}

Our arguments, if they are correct, suggest that the traditional view of how capitalist economies work is at best oversimplified and at worst simply wrong. Managers have considerable discretion: the control mechanisms work only imperfectly. Though the earlier Berle-Means view that managers control firms and the March-Simon view that they simply satisfice may be incomplete, these views may provide a more accurate description of firm behavior than the other extreme view that firms maximize their stock market value. Managers face a variety of constraints and a variety of incentives, imposed by a variety of institutions. Managers of large corporations whose stock is widely held undoubtedly behave in ways which are

\footnotetext{
${ }^{48}$ Their position should be contrasted with that of the owner-manager under primitive capitalism, whose dynastic ambitions included leaving his firm to his heirs. Such individuals were not concerned with what they might be able to sell their firm for on a day-to-day basis, but with the long-term prospects of the firm.

Evidence that managers are particularly concerned with the short-run prospects of the firm is provided by such so-called tax paradoxes as the extensive use of FIFO inventory accounting in inflationary times and the long lags in the shift to accelerated depreciation. The standard explanation of these phenomena is that managers were concerned that, were they to make these changes, the market would misinterpret the decline in accounting profits, and as a result the current market price would decline. This decline would occur despite the fact that the real (after tax) value of the firm should have increased. (If investors continued to behave naively on the basis of current reported profits, future values would eventually increase.)

Clearly, if the current market price accurately reflected the long-run prospects of the firm, there would be no discrepancy between maximizing current market valuation and long-run market valuation. In an economy in which there is an incomplete set of risk and futures markets, and investors are imperfectly informed concerning the activities of the firm, there is no reason to believe that the two will be perfectly congruent. The tax paradoxes described earlier provide illustrations of this.
} 
markedly different from that of an owner-manager. We have identified a number of biases: lenders are more concerned with avoiding defaults than with maximizing returns, and managers are more concerned with short-run profitability than the long-run prospects of the firm.

The question arises, are there some institutional reforms which, if not ensuring complete efficiency, at least may improve matters?

Before putting forward some tentative suggestions, let me restate what I see to be the problems. First, the resources required by most large industrial enterprises are beyond the capabilities of any single individual; or even if one individual had the resources, he would have to bear more risk than he would like. What has evolved is a system in which there are two (or occasionally more) broadly defined classes of suppliers of capital. One class (equity) has a large number of participants; for each, the management of the firm represents a public good; because the effective exercise of control is costly, each individual is willing to be a free rider, and the consequence is that this class, which has nominal control, cannot effectively exercise it. The other class, lenders, has a small number of participants, and the institutional arrangements provide a mechanism by which the free-rider problems can be alleviated. Each of these classes has its own interests and its limited means of control. It is as if there is a multiple-principal/single-agent (or multiple-agent) problem, for which the Nash equilibrium (even ignoring the free-rider problems) is not efficient.

Our objective then is to find institutional arrangements that reduce the free-rider problem, that extend control to those for whom information is relatively costless, and that provide incentive structures such that those who are in a position to exercise control take into account the consequences for all the affected groups.

There are two tentative suggestions that I wish to put forward. Neither is without its problems. While I am not convinced that these reforms are desirable, I am convinced that there is considerable scope for institutional innovation in our economy: the malaise of our economy, as well as our theoretical analysis, suggests that we cannot rely on nineteenth-century ideology for our views of how the economy should be organized.

Both suggestions are based on the recognition of the importance of costs of monitoring: to have control effectively exercised, those exercising it must have a strong incentive for doing so. There are two institutions that have such incentives: banks and unions (as representatives of the workers).$^{49}$ One of the central problems with banks' exercise of their control function was their excessive concern for the lower tail of the distribution. This bias might be alleviated by allowing banks (or perhaps better, a related but independent subsidiary) to own equity shares in firms. Information could be shared between the bank and its equity subsidiary; and the bank, in exercising its control over the management, might be induced to look not only towards the bottom tail of the distribution of returns, but also towards the mean. ${ }^{50}$

\footnotetext{
${ }^{49}$ If labor markets were perfectly competitive, and there were no costs associated with individuals changing jobs, then workers would have little interest in the prospects of their firms; but both assumptions are counterfactual.

${ }^{50}$ This proposal is not without its problems: the bank, knowing that its depositors are insured through the FDIC, might be willing to expose them to greater risks, in order to earn greater return on its equity subsidiary.
} 
The other major institution that is in a position to extend its powers of control is the unions. They have one advantage over virtually all other institutions: they (or their members) are intimately involved in the day-to-day functioning of the firm, and hence the costs of acquiring (certain kinds of) information concerning the firm are likely to be less than for others. They have a second advantage: they, like the banks, have a strong interest in the survival of the firm. The workers collectively may have the largest undiversified stake in the firm. ${ }^{51}$ It has increasingly become recognized that the traditional adversarial role between management and workers is inappropriate: it is not a zero sum game. We have argued that workers (unions) have both the information base and the incentive to exercise surveillance and control. But will they do so only in their own narrow interests? The development of huge pension funds provides a vehicle by which a greater coincidence of interests can be achieved: if a significant fraction of the pension funds are invested in the firm, they will have an interest in ensuring that the managers take actions which are in the interests of shareholders as well. Employee stock ownership programs may go even further in reducing the divergence of interests between workers and shareholders. ${ }^{52}$

There has long been a tradition that workers should work, and managers manage. This separation of functions may have been appropriate under primitive capitalism; but as we have argued, the problem of a modern joint stock company is not appropriately modeled as a single-principal/multiple-agent problem; rather it is a multiple-principal/multiple-agent problem, for which the Nash equilibrium is almost invariably inefficient. Each participant (or class of participants) pursuing his own interests, given the set of controls at his disposal, results in resource allocations

The recent episodes of large banks becoming overly committed to certain classes of correlated risks (oil and gas loans; loans to LDCs) raises questions concerning the ability of banks to perform the control functions that are under discussion here; it has been suggested that given the insurance provided by the FDIC (both explicit and implicit) these decisions may indeed have been the correct ones from the perspective of expected return to the owners, of the bank, or in any case were natural consequences of the incentive structures facing loan officers.

Concerns about banks using their position to restrict competition are, I suspect, exaggerated, so long as the industries are subject to international competitive pressures and so long as the FTC and Justice Department maintain surveillance over anticompetitive practices. Moreover, what is at issue is not turning over all control to these banking institutions, only extending their roles to induce them to take the interests of shareholders more into account.

Throughout the discussion I have assumed that banks are concerned with avoiding defaults. Though banks should be concerned with this, I have frequently been asked in presentations of this talk if there is not a similar principal-agent problem facing banks. How do we know that the bank loan officers do not pursue some other policies? And if they do not, are we not simply shifting the focus of control from one set of managers (those of the firms) to another set of managers (those of the banks)? In reply, I have two comments. First, I am not arguing that managers are completely uncontrolled, but rather that they have a large amount of discretion. At the same time, I believe that a change in the incentives structures (payoffs) to the bank will be reflected in the incentive structures facing its managers, at least to some extent. Second, I am not arguing here that these banks (bank managers) should be given more control, but that we should consider alternative institutional arrangements which will make it more likely that they take actions more in accord with the interests of shareholders.

${ }^{51}$ In the event of a bankruptcy, the loss to workers (the wages lost while they find alternative unemployment, and the return to specific training loss) may exceed the loss to the suppliers of capital. Moreover, these losses may represent, individually, a larger fraction of the wealth of workers than the corresponding losses are for the suppliers of capital.

${ }^{52}$ This proposal too is not without its problems. To the extent that workers invest their saving (pensions) in the firm, they bear greater risks than they otherwise would.

Moreover, it is not always clear that unions act in the interests of their members. Unions can be viewed as an attempt to solve the problem of public good for workers, but as in any such institution, there is always the possibility of significant differences between the interests of the elected officials and those they are intended to serve. 
that are not Pareto efficient. The actions of each group have important consequences for all other groups (there are important externalities). Moreover, we have repeatedly made note of the public good nature of good management: that it is not in the interests of any small member of the class of capital suppliers to devote resources to ensure that the interests of his class are pursued by the firms' managers. (And to the extent that actions which benefit the members of one class have spillovers onto members of other groups, each group's supply of "surveillance" services will be too small.)

Our problem is to design insitutional structures that serve to internalize some of these externalities, that take advantage of those who are in the best position to obtain information and exercise control (surveillance), and that can ameliorate (although obviously not eliminate) some of the free-rider problems which are inherent in the maintenance of good management. The two proposals we have put forward here are aimed at those objectives: whether they go far enough or whether they would be accompanied by more than offsetting advantages remains to be seen. ${ }^{53}$

At the very least, I hope my analysis has convinced you of the inappropriateness of the nineteenth-century model of owner-manager capitalism as a description of twentieth-century capitalism. There is no simple answer to the question of who controls the firm. But what is clear is that minority shareholders do not exercise control, that banks are in a better position to exercise some control over managers, and that to the extent that they do exercise control, there are important biases in the decisions made. Our system may work well, but I suspect that there is room for improvement: social innovations are no less important than technological innovations. ${ }^{54}$

\section{LITERATURE CITED}

Abreu, Dilip. "Repeated Games with Discounting: A General Theory and an Application to Oligopoly." Ph.D. dissertation, Princeton University, 1983.

Akerlof, George A. "The Market for 'Lemons': Quality Uncertainty and" the Market Mechanism." Quarterly Journal of Economics 84 (August 1970), 488-500.

\footnotetext{
${ }^{53}$ There are other reforms that, I think, might also improve matters. Managers might be encouraged to take a longer-run interest in the firm, for instance, by having part of their compensation based on the performance five, ten, or fifteen years into the future.

Tax laws that encourage shareholders to hold on to their shares for long periods of time, while they have a deleterious effect on liquidity, may encourage greater concern for the long-run profitability of the firm.

Attempts to restrict certain practices, where shareholder interest and manager interest seem most obviously in conflict (such as some golden parachutes) may have some salutary effect. But they are likely to provide only symptomatic relief - from the most obvious and publicly visible symptoms of the differences between managers' and shareholders' interests; the underlying problems will remain.

There are organizational forms by which large amounts of capital from a large number of individuals may be raised, but in which the problem of public good may be reduced: assume each firm were restricted to having at most ten shareholders. These firms would then invest in larger firms (but again, each of the larger firms would be limited to ten investors, where the investors are "firms" rather than individuals). At each stage, the number of investors is sufficiently small that the problem is greatly attenuated. This system has the disadvantage that there is now a "chain" of principal-agent relationships. The inefficiencies associated with such chains is a subject under current investigation.

${ }^{54}$ At the same time, it is important to bear in mind that the systems for control of capital which have evolved in other successful economies, such as Germany and Japan, are markedly different from that of the United States. It is worth inquiring whether the explanation for these differences is related to particular legal restrictions or to some other aspects of the economy, or whether it is simply a historical accident.
} 
Allen, Franklin. "Capital, Sharecropping, Ability and Information." Mimeographed. Oxford: Oxford University, 1980.

Arnott, Richard, and Joseph E. Stiglitz. "The Welfare Economics of Moral Hazard." Mimeographed. Princeton, N.J.: Princeton University, November 1983 (a).

"Moral Hazard and Optimal Commodity Taxation." National Bureau of Economic Research, Working Paper No. 1154, June 1983 (b).

Baumol, William J. Business Behavior, Value, and Growth. New York: Harcourt, Brace \& World, 1967.

Berle, Adolf A., Jr. "Non-Voting Stock and 'Bankers' Control." Harvard Law Review (1926).

Power Without Property. New York: Harcourt, Brace, 1959.

Berle, Adolf A., Jr., and Gardiner C. Means. The Modern Corporation and Private Property. New York: Macmillan, 1932.

Bernheim, B. Douglas, and Michael D. Whinston. "Common Agency." Mimeographed. Stanford, Calif.: Stanford University, 1984.

Blinder, Alan S., and Joseph E. Stiglitz. "Money, Credit Constraints, and Economic Activity." American Economic Review, Papers and Proceedings 73 (May 1983), 297-302.

Braverman, Avishay, and Joseph E. Stiglitz. "Sharecropping and the Interlinking of Agrarian Markets." American Economic Review 72 (September 1982), 695-715.

Cary, W. "Corporate Devices Used to Insulate Management from Attack." Anti-trust Law Journal (1969-70), 318.

"Corporations and Private Property." Journal of Law and Economics 26 (June 1983). Special issue with papers by Thomas G. Moore; George J. Stigler and Clare Friedland; Douglas C. North; R. Hessen; Nathan Rosenberg; Gardiner C. Means; Eugene Fama and Michael C. Jensen; Oliver E. Williamson; Burt Klein; Harold Demsetz; Rita Ricardo-Campbell; Frank Easterbrook and D. Fischel; Leonard W. Weiss; J. S. McGee; and C. Baldwin.

Diamond, Peter A., and Joseph E. Stiglitz. "Increases in Risk and in Risk Aversion." Journal of Economic Theory 8 (July 1974), 337-60.

Greenwald, Bruce. "Adverse Selection in the Labor Market." Review of Economic Studies (1984), in press.

Greenwald, Bruce, and Joseph E. Stiglitz. "Pecuniary and Market Mediated Externalities: Towards a General Theory of the Welfare Economics of Economies with Imperfect Information and Incomplete Markets.".National Bureau of Economic Research, Working Paper No. 1304, March 1984.

Greenwald, Bruce, Joseph E. Stiglitz, and Andrew Weiss. "Informational Imperfections in the Capital Market and Macro-Economic Fluctuations." American Economic Review, $\mathrm{Pa}$ pers and Proceedings 74 (May 1984), 194-200.

Grossman, Sanford J., and Oliver D. Hart. "Takeover Bids, the Free-Rider Problem, and the Theory of the Corporation." Bell Journal of Economics 11 (Spring 1980), 42-64.

"The Allocational Role of Takeover Bids in Situations of Asymmetric Information." Journal of Finance 36 (May 1981), 253-70.

"Corporate Financial Structure and Managerial Incentives." In Economics of Information and Uncertainty, edited by John McCall, pp. 107-40. Chicago: University of Chicago Press, 1982.

Grossman, Sanford J., and Joseph E. Stiglitz. "Information and Competitive Price Systems." American Economic Review 66 (May 1976), 246-53.

"On Value Maximization and Alternative Objectives of the Firm." Journal of Finance 32 (May 1977), 389-402.

"Stockholder Unanimity in Making Production and Financial Decisions." Quarterly Journal of Economics 94 (May 1980), 543-66 (a). 
"On the Impossibility of Informationally Efficient Markets." American Economic Review 70 (June 1980), 393-408 (b).

Jensen, Michael C., and William H. Meckling. "Theory of the Firm: Managerial Behavior, Agency Costs, and Ownership Structure." Journal of Financial Economics 3 (October 1976), 305-60.

Keeton, William R. Equilibrium Credit Rationing. New York: Garland, 1979.

Larson, John. "Why Long Term Incentives Fail." Paper presented to a Conference on the Economics of Incentive, Cooperation, and Risk Sharing." New York University, March 1984.

Leland, Hayne E., and David H. Pyle. "Informational Asymmetries, Financial Structure, and Financial Intermediation." Journal of Finance 32 (May 1977), 371-87.

Manne, Henry G. "Mergers and the Market for Corporate Control." Journal of Political Economy 73 (April 1965), 110-20.

Nalebuff, Barry J., and Joseph E. Stiglitz. "Prizes and Incentives: Towards a General Theory of Compensation and Competition." Bell Journal of Economics 14 (Spring 1983), 21-43.

Ross, Stephen A. "The Economic Theory of Agency: The Principal's Problem." American Economic Review, Papers and Proceedings 63 (May 1973), 134-39.

"The Determination of Financial Structure: The Incentive-Signalling Approach." Bell Journal of Economics 8 (Spring 1977), 23-40.

Shapiro, C., and Joseph E. Stiglitz. "Equilibrium Unemployment As a Worker Discipline Device." American Economic Review 74 (June 1984), 443-45.

Stiglitz, Joseph E. "On the Optimality of the Stock Market Allocation of Investment." Quarterly Journal of Economics 86 (Febnuary 1972), 25-60 (a).

"Some Aspects of the Pure Theory of Corporate Finance: Bankruptcies and Take-overs." Bell Journal of Economics and Management Science 3 (Autumn 1972), $458-82$ (b).

"Incentives and Risk Sharing in Sharecropping." Review of Economic Studies 41 (April 1974), 219-55.

"Information and Economic Analysis." In Current Economic Problems, edited by Michael Parkin and A. Robert Nobay, pp. 27-52. Cambridge: Cambridge University Press, 1975 (a).

"Monopolistic Competition and the Capital Market." IMSSS Technical Report No.

161. Stanford, Calif.: Stanford University, February 1975 (b).

"Theory of Local Public Goods." In The Economics of Public Services, edited by Martin S. Feldstein and Robert P. Inman, pp. 274-333. London: Macmillan, 1977.

"Pareto Optimality and Competition." Journal of Finance 36 (May 1981), 235-51.

"Ownership, Control, and Efficient Markets: Some Paradoxes in the Theory of Capital Markets." In Economic Regulation: Essays in Honor of James R. Nelson, edited by Kenneth D. Boyer and William C. Shepherd, pp. 311-41. Ann Arbor, Mich.: Michigan State University Press, 1982 (a).

"Information and Capital Markets." In Financial Economics: Essays in Honor of Paul Cootner, edited by William F. Sharpe and Cathryn M. Cootner, pp. 118-58. Englewood Cliffs, N.J.: Prentice Hall, 1982 (b).

Stiglitz, Joseph E., and Andrew Weiss. "Credit Rationing in Markets with Imperfect Information." American Economic Review 71 (June 1981), 393-410.

"Incentive Effects of Terminations: Applications to the Credit and Labor Markets." American Economic Review 73 (December 1983), 912-27.

Tiebout, Charles M. "A Pure Theory of Local Expenditures." Journal of Political Economy 64 (August 1956), 416-24. 
Copyright of Journal of Money, Credit \& Banking is the property of Ohio State University Press and its content may not be copied or emailed to multiple sites or posted to a listserv without the copyright holder's express written permission. However, users may print, download, or email articles for individual use. 